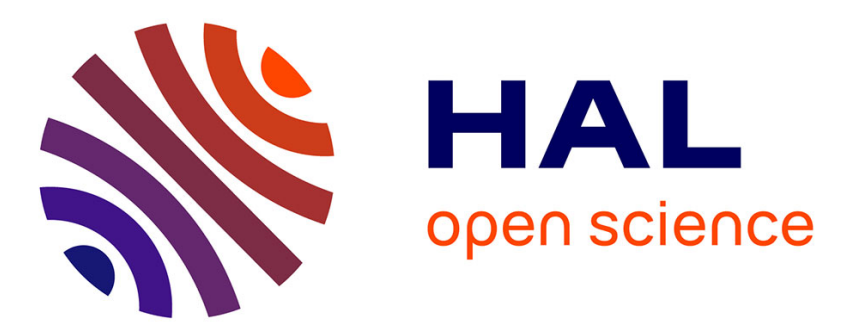

\title{
Hydrogen sulphide quantification by SIFT/MS: highlighting the influence of gas moisture
}

Leticia Vitola Pasetto, Romain Richard, Jean-Stéphane Pic, Marie-Hélène Manero, Frédéric Violleau, Valérie Simon

\section{- To cite this version:}

Leticia Vitola Pasetto, Romain Richard, Jean-Stéphane Pic, Marie-Hélène Manero, Frédéric Violleau, et al.. Hydrogen sulphide quantification by SIFT/MS: highlighting the influence of gas moisture. International Journal of Environmental Analytical Chemistry, 2020, 100 (10), pp.1133-1145. 10.1080/03067319.2019.1650919 . hal-02278814

\section{HAL Id: hal-02278814 \\ https://hal.science/hal-02278814}

Submitted on 4 Sep 2019

HAL is a multi-disciplinary open access archive for the deposit and dissemination of scientific research documents, whether they are published or not. The documents may come from teaching and research institutions in France or abroad, or from public or private research centers.
L'archive ouverte pluridisciplinaire HAL, est destinée au dépôt et à la diffusion de documents scientifiques de niveau recherche, publiés ou non, émanant des établissements d'enseignement et de recherche français ou étrangers, des laboratoires publics ou privés. 


\section{OATAO}

Open Archive Toulouse Archive Ouverte

\section{Open Archive Toulouse Archive Ouverte}

OATAO is an open access repository that collects the work of Toulouse researchers and makes it freely available over the web where possible

This is an author's version published in: http://oatao.univ-toulouse.fr/24301

Official URL: https://doi.org/10.1080/03067319.2019.1650919

\section{To cite this version:}

Vitola Pasetto, Leticia $\leftrightarrows$ and Richard, Romain $\leftrightarrows$ and Pic, Jean-Stéphane and Manero, Marie-Hélène $\leftrightarrows$ and Violleau, Frédéric $\stackrel{5}{\leftrightarrows}$ and Simon, Valérie Hydrogen sulphide quantification by SIFT/MS: highlighting the influence of gas moisture. (2019) International Journal of Environmental Analytical Chemistry. ISSN 0306-7319

Any correspondence concerning this service should be sent to the repository administrator: tech-oatao@listes-diff.inp-toulouse.fr 


\title{
Hydrogen sulphide quantification by SIFT/MS: highlighting the influence of gas moisture
}

\author{
Leticia Vitola Pasetto ${ }^{\mathrm{a}, \mathrm{b}}$, Romain Richard (D) , Jean-Stéphane Pic ${ }^{\mathrm{c}}$, Marie- \\ Hélène Manero (iD ${ }^{a}$, Frédéric Violleau (iD ${ }^{b}$ and Valérie Simon $\left(\mathrm{DD}^{\mathrm{b}}\right.$ \\ aLaboratoire de Génie Chimique, Université de Toulouse, CNRS, INPT, UPS, Toulouse, France; 'Laboratoire \\ de Chimie Agro-industrielle, LCA, Université de Toulouse, INRA, INPT, Toulouse, France; 'Toulouse \\ Biotechnology Institute, Bio \& Chemical Engineering, TBI, Université de Toulouse, CNRS, INRA, INSA, \\ Toulouse, France
}

\begin{abstract}
The quantification of hydrogen sulphide $\left(\mathrm{H}_{2} \mathrm{~S}\right)$ by Selected lon Flow Tube coupled with Mass Spectrometry (SIFT/MS) was investigated for application in industrial emission context, usually faced with concentrations of water vapour higher than the saturation at room condition. $\mathrm{H}_{2} \mathrm{~S}$ concentrations measured by SIFT/MS (using nitrogen as carrier gas and flow tube temperature at $119^{\circ} \mathrm{C}$ ) were affected by water content, reducing the sensibility for $\mathrm{H}_{2} \mathrm{~S}$ measurements. Accurate concentrations were obtained when the influence of water was considered on SIFT/MS analysis, requiring although the information about water content in the sample. In addition, the association of low concentration of $\mathrm{H}_{2} \mathrm{~S}$ (around $50 \mathrm{ppbv}$ ) and high humidity level ( $4.0 \% \mathrm{vol}$ of water) was highlighted as a critical point for measuring $\mathrm{H}_{2} \mathrm{~S}$ by SIFT/MS, due to the sensibility reduction as function of water content and the measurement uncertainty enhancement at low signal intensity.
\end{abstract}

\section{KEYWORDS}

Chemical ionisation mass spectrometry; hydrogen sulphide; water interference; selected ion flow tube mass spectrometry

\section{Introduction}

Reduced sulphur compounds (RSCs) are key-compounds in Environmental Chemistry due to their association to acid rain, odour nuisance and potential health hazard [1-3]. They are emitted from natural and industrial activities, such as volcanic eruptions, landfills, wastewater treatments, pulp-and-paper and chemical plants [4,5]. Allying its low odour threshold limit $(0.15 \mathrm{ppbv}$ [6]) to its common detection in polluted atmospheric analysis [4,7], hydrogen sulphide $\left(\mathrm{H}_{2} \mathrm{~S}\right)$ was chosen as a model compound for RSCs. Furthermore, $\mathrm{H}_{2} \mathrm{~S}$ is the major impurity in the natural gas, which concentration must be monitored to ensure the regulatory level $[8,9]$.

Several analytical methods have been developed to quantify $\mathrm{H}_{2} \mathrm{~S}$. Those based on Gas Chromatography (GC) are the most used techniques, in combination with specific sulphur detectors such as Electron Capture Detector (ECD), Flame Photometric Detector (FPD), Pulsed Flame Photometric Detector (PFPD), Sulphur Chemiluminescence Detector (SCD) and Atomic Emission Detection (AED) [2,3]. The analysis of $\mathrm{H}_{2} \mathrm{~S}$ based on GC usually applies 
a Thermodesorption (TD) device to obtain lower limit of detection (LOD). Even if interesting LOD values could be achieved by GC methods, chromatographic and sampling interferences can still occur in presence of water and oxidants (such as ozone, sulphur dioxide and nitrogen oxides) $[2,4]$.

More recently and in parallel to GC-based methods, the use of Chemical lonization coupled with Mass Spectrometry (ICMS) has been reported in literature for $\mathrm{H}_{2} \mathrm{~S}$ quantification [9-12]. Real-time analysis, high sensitivity and low LOD are some of the advantages common to ICMS techniques, such as Proton Transfer Reaction Mass Spectrometry (PTR/MS) and Selected lon Flow Tube Mass Spectrometry (SIFT/MS). For both PTR/MS and SIFT/MS, $\mathrm{H}_{2} \mathrm{~S}$ concentration is calculated based on the ionisation reaction of $\mathrm{H}_{2} \mathrm{~S}$ with $\mathrm{H}_{3} \mathrm{O}^{+}$precursor ion, which generates the $\mathrm{H}_{3} \mathrm{~S}^{+}$product ion, since the proton affinity of $\mathrm{H}_{2} \mathrm{~S}\left(705 \mathrm{~kJ} \mathrm{~mol}^{-1}\right)$ is higher than $\mathrm{H}_{2} \mathrm{O}(691 \mathrm{~kJ}$ $\left.\mathrm{mol}^{-1}\right)[9,10,12]$. However, this slight difference on proton affinity values may lead to a more complex analysis of $\mathrm{H}_{2} \mathrm{~S}$ than usual.

Previously studies regarding the quantification of $\mathrm{H}_{2} \mathrm{~S}$ in humid air by PTR/MS $[9,12]$ have demonstrated that, in presence of water, the reverse ionisation reaction (proton transfer from $\mathrm{H}_{3} \mathrm{~S}^{+}$to $\mathrm{H}_{2} \mathrm{O}$ ) occurs and $\mathrm{H}_{2} \mathrm{~S}$ concentrations must be corrected regarding the water content. In addition, it was reported a decrease on the sensitivity of PTR/MS when analysing $\mathrm{H}_{2} \mathrm{~S}$ in presence of water [9]. Similar disturbance on $\mathrm{H}_{2} \mathrm{~S}$ measurements due to humidity presence was also observed in SIFT/MS analysis [10] and thus, accurate $\mathrm{H}_{2} \mathrm{~S}$ concentrations are only possible if the secondary reactions of $\mathrm{H}_{3} \mathrm{~S}^{+}$are considered. Furthermore, the water clusters formation of $\mathrm{H}_{3} \mathrm{~S}^{+} \cdot \mathrm{H}_{2} \mathrm{O}$ and $\mathrm{H}_{3} \mathrm{O}^{+} .\left(\mathrm{H}_{2} \mathrm{O}\right)_{n=1,2,3}$ (hydrated hydronium ions) must be taking into account [10]. In addition to the proton transfer from $\mathrm{H}_{3} \mathrm{~S}^{+}$to $\mathrm{H}_{2} \mathrm{O}$, Spanel and Smith [10] have indicated the exothermic switching reaction of $\mathrm{H}_{3} \mathrm{~S}^{+} .\left(\mathrm{H}_{2} \mathrm{O}\right)_{n=1,2}$ with $\mathrm{H}_{2} \mathrm{O}$ (generating $\mathrm{H}_{3} \mathrm{O}^{+} .\left(\mathrm{H}_{2} \mathrm{O}\right)_{n=1,2}$ and $\mathrm{H}_{2} \mathrm{~S}$ ) may also occur. According to another study from Spanel and Smith [13], the clusters formation happens via sequential three-body association, in which helium molecule (carrier/inert gas) present at the reaction chamber (flow tube) acts as stabilising-agent. Therefore, as $\mathrm{H}_{2} \mathrm{~S}$ quantification depends on the water clusters generation, which in turn is influenced by the inert compound, the use of a different molecule as carrier gas could lead to distinct results in terms of $\mathrm{H}_{2} \mathrm{~S}$ quantification in humid air.

In this work, the influence of humidity in the quantification of $\mathrm{H}_{2} \mathrm{~S}$ by SIFT/MS was deeper investigated to adequate SIFT/MS analysis for industrial emission context (usually faced with humidity content higher than atmospheric level [14-16]). The impact of the humidity on $\mathrm{H}_{2} \mathrm{~S}$ quantification was investigated by monitoring the sensibility and the uncertainty of SIFT/MS device (which was operated in different conditions compared to those reported in the literature [10], i.e. higher flow tube temperature and nitrogen as carrier gas). In addition, an empirical model was proposed to satisfactorily quantify $\mathrm{H}_{2} \mathrm{~S}$ concentrations even in extreme humidity conditions.

\section{Experimental}

\subsection{Materials}

The $\mathrm{H}_{2} \mathrm{~S}$ calibration was performed between 0.05 and $1.6 \mathrm{ppmv}$ (in 6 levels) from the mix of a gas cylinder standard (100 ppmv of $\mathrm{H}_{2} \mathrm{~S}$ in nitrogen, Air Liquide, France) and an air stream (ZR55, oil-free air ISO 8573-1 class 0, Atlas Copco France) integrated to air filter 
(Olympian Plus, Norgren, UK), which gas flows were controlled by mass flowmeters (SLA 5850S-B Brooks Instruments, USA). A humidification system (Serv'Instrumentation, France) was employed to generate calibrated water content $\left(\left[\mathrm{H}_{2} \mathrm{O}\right]\right)$ from $0.01 \%$ vol (dry air, dew point equal to $-40^{\circ} \mathrm{C}$ at $101.3 \mathrm{kPa}$ ) until $5.00 \% \mathrm{vol}$ (dew point equal to $33^{\circ} \mathrm{C}$ at $101.3 \mathrm{kPa}$ ), in 7 levels, which are described in Table 1. When water concentration reaches $2.00 \% \mathrm{vol}$ (equivalent to dew point of $17^{\circ} \mathrm{C}$ ), the air stream is nearly saturated ( $>80 \%$ of relative humidity) at room conditions $\left(20^{\circ} \mathrm{C}\right.$ and $101.3 \mathrm{kPa}$ ). Therefore, for the conditions when water content was superior to $2.00 \%$ vol, the system was heated until $40^{\circ} \mathrm{C}$ thanks to a hot circulating oil bath (Model 1160S, VWR, USA), composed of a stainless steel smooth-coil immersed in a synthetic thermoliquid (Ultra 350, Lauda, Germany) installed at the air line after the humidification system. The gas line between the mixture point and the SIFT/MS was isolated and heated using a heated cable (FGR-100, Omegalux, France) to prevent condensation.

\subsection{SIFT-MS analysis}

In SIFT/MS system, $\mathrm{H}_{2} \mathrm{~S}$ concentration is determined thanks to the reaction of the molecule with the $\mathrm{H}_{3} \mathrm{O}^{+}$precursor ion and the detection of its product ion by MS. Produced by a microwave discharge in SIFT/MS device (Voice 200ultra, Syft Technologies Ltd, New Zealand), the precursor ion was selected by a first quadrupole mass filter and

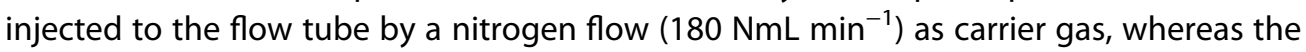

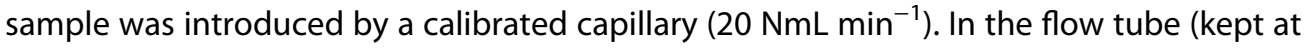
$119^{\circ} \mathrm{C}$ and $0.07 \mathrm{kPa}$ ), the reaction between the analyte (neutral compound) and the selected precursor ion was held, generating product ions with specific mass-to-charge ratios $(\mathrm{m} / \mathrm{z})$. The product ions were quantified by a second quadrupole mass spectrometer, calculating a count rate (signal intensity in counts $\mathrm{s}^{-1}$ ) [17-19].

The analyte present in the sample $\left([A]_{\text {sample }}\right)$ was diluted by the carrier gas in the flow tube, whose analyte concentration $\left([A]_{f t}\right)$ depends on the operating conditions of the flow tube - temperature $\left(T_{f t}\right)$, pressure $\left(P_{f t}\right)$, sample flow $\left(\varphi_{s}\right)$, carrier gas flow $\left(\varphi_{c}\right)$ - and on the Boltzmann constant $\left(k_{b}\right)$, as described by Equation (1) [17].

$$
[\mathrm{A}]_{\mathrm{ft}}=[\mathrm{A}]_{\text {sample }} \frac{\mathrm{P}_{\mathrm{ft}}}{\mathrm{T}_{\mathrm{ft}} \mathrm{k}_{\mathrm{b}}} \frac{\varphi_{\mathrm{s}}}{\left(\varphi_{\mathrm{s}}+\varphi_{\mathrm{c}}\right)}
$$

$[A]_{f t}$ was also calculated by Equation (2) based on the rate coefficient $(k)$ of the reaction between the neutral compound and the precursor ion, the reaction time in the flow tube $(t)$, the ratio between the precursor ion count rate at time equal to $0\left(\left[I_{0}\right]\right)$ and time $\mathrm{t}([I])[17,20]$. For the Syft model used for this project, reaction time was around $5 \mathrm{~ms}$.

Table 1. Levels of humidity in the air sample studied at atmospheric pressure.

\begin{tabular}{lccc}
\hline$\left[\mathrm{H}_{2} \mathrm{O}\right](\%$ vol $)$ & Dew point $\left({ }^{\circ} \mathrm{C}\right)$ & Air temperature $\left({ }^{\circ} \mathrm{C}\right)$ & Relative humidity $(\%)$ \\
\hline 0.01 & -40 & 20 & 0 \\
0.50 & -3.5 & 20 & 20 \\
1.20 & 9.5 & 20 & 50 \\
2.00 & 17 & 20 & 75 \\
2.30 & 20 & 40 & 35 \\
3.50 & 26 & 40 & 50 \\
5.00 & 33 & 40 & 70 \\
\hline
\end{tabular}




$$
\frac{[\mathrm{I}]}{[\mathrm{I}]_{0}}=\exp \left(-\mathrm{k}[\mathrm{A}]_{\mathrm{ft}} \mathrm{t}\right)
$$

As the product ion count rate $([\mathrm{P}])$ can be expressed as the difference between $[I]_{0}$ and $[I]$ (in case of mono-component and $\mathrm{m} / \mathrm{z}$ inferior to 100 [21]), Equation (2) becomes Equation (3).

$$
\frac{[\mathrm{P}]}{[\mathrm{I}]}=\frac{1-\exp \left(-\mathrm{k}[\mathrm{A}]_{\mathrm{ft}} \mathrm{t}\right)}{\exp \left(-\mathrm{k}[\mathrm{A}]_{\mathrm{ft}} \mathrm{t}\right)}
$$

At low analyte concentrations, Equation (3) can be approximated to a linear correlation between $[A]_{f t}$ and $[P] /[I]$ ratio (Equation 4 ), if the limit of $k[A]_{f t} t$ approaching zero is considered in the exponential expression [17]. This linear approximation is only valid for small values of $[P] /[I](\ll 1)$. Moreover, Equation (4) also integrates the diffusion-correcting factor $\left(D_{f}\right)$, which is usually assumed as unity except when the size of the precursor and the product ion is greatly different $[17,21]$. In presence of water, clusters ions are likely generated and therefore, the count rates of all product ions originated from analyte $A$, and all secondary clusters precursor ions with its respective rate coefficient must be taking into account to correctly calculate $[A]_{f t}[17]$.

$$
[A]_{f t}=\frac{D_{f}}{t} \frac{\sum_{i=1}^{n}\left[P_{i}\right]}{\sum_{j=1}^{m}\left[l_{j}\right] k_{j}}
$$

In case of $\mathrm{H}_{2} \mathrm{~S}$, rate coefficients proposed in the kinetic library from LabSyft ${ }^{\circledR}$ 1.6.2 (analytical software related to SIFT/MS instrument, Syft Technologies Ltd, New Zealand) are shown in Table 2 for helium as carrier gas. These values are in agreement with several studies in the literature $[10,11,22]$. Two product ions are proposed: $\mathrm{H}_{3} \mathrm{~S}^{+}$ with $\mathrm{m} / \mathrm{z}$ ratio equal to 35 and $\mathrm{H}_{3} \mathrm{~S}^{+} .\left(\mathrm{H}_{2} \mathrm{O}\right)$ with $\mathrm{m} / \mathrm{z}$ equal to 53 .

According to studies carried out by Milligan et al. [23], in SIFT/MS instrument, LOD is calculated considering the confidence level equal to three standard deviations above background, whereas limit of quantification (LOQ) is the lowest concentration that can be measured with a precision of $\pm 20 \%[18,23]$. These concentrations are obtained by Equation (5) (LOD) and Equation (6) (LOQ), where $b_{\mu}$ represents the mean background count rate (counts $\mathrm{s}^{-1}$ ) of the product ion at specific $\mathrm{m} / \mathrm{z}$ ratio, $t_{m}$ the measurement time (s) and $s$ the sensitivity (counts $\mathrm{s}^{-1} \mathrm{ppbv}^{-1}$ ). In this study, $b_{\mu}$ and $t_{m}$ were calculated from a blank analysis, i.e. without the presence of the analyte $\left(\mathrm{H}_{2} \mathrm{~S}\right)$, but still injecting air at its respective humidity content in the SIFT/MS instrument $\left(b_{\mu}\right.$ represents the global blank, whose noise value was related to the experimental set-up and the SIFT/MS device). Sensitivity was defined as the number of product ions (counts $\mathrm{s}^{-1}$ ) at the specific $\mathrm{m} / \mathrm{z}$ ratio produced for a given concentration of analyte $[24,25]$. It is important to highlight

Table 2. Rate coefficients of $\mathrm{H}_{2} \mathrm{~S}$.

\begin{tabular}{lc}
\hline Precursor ion & Rate coefficient $\left(\mathrm{cm}^{3}\right.$ molecule $\left.\mathrm{s}^{-1} \mathrm{~s}^{-1}\right)$ \\
\hline $\mathrm{H}_{3} \mathrm{O}^{+}(\mathrm{m} / \mathrm{z} 19)$ & $1.6 \times 10^{-9}$ \\
$\mathrm{H}_{3} \mathrm{O}^{+} .\left(\mathrm{H}_{2} \mathrm{O}\right)(\mathrm{m} / \mathrm{z} 37)$ & $5 \times 10^{-12}$ \\
$\mathrm{H}_{3} \mathrm{O}^{+} .\left(\mathrm{H}_{2} \mathrm{O}\right)_{2}(\mathrm{~m} / \mathrm{z} 55)$ & $5 \times 10^{-12}$ \\
$\mathrm{H}_{3} \mathrm{O}^{+} .\left(\mathrm{H}_{2} \mathrm{O}\right)_{3}(\mathrm{~m} / \mathrm{z} 73)$ & $5 \times 10^{-12}$ \\
\hline
\end{tabular}


that, in SIFT/MS analysis, the measurement time affects the LOD and LOQ values (the longer the measurement, the lower LOD and LOQ).

$$
\begin{gathered}
\mathrm{LOD}_{\mathrm{ppbv}}=\frac{3 \sqrt{\mathrm{b}_{\mu} t_{m}}}{\mathrm{~s} t_{m}} \\
\mathrm{LOQ}_{\mathrm{ppbv}}=\frac{25+5 \sqrt{25+4 \mathrm{~b}_{\mu} \mathrm{t}_{\mathrm{m}}}}{2 \mathrm{st} \mathrm{t}_{\mathrm{m}}}
\end{gathered}
$$

\section{Results and discussion}

\subsection{Accurate $\mathrm{H}_{2} \mathrm{~S}$ concentration in presence of water}

Even applying different operating conditions on SIFT/MS device (flow tube temperature at $119^{\circ} \mathrm{C}$ and nitrogen as carrier gas), the injection of a humid air has greatly promoted the water clusters formation, as it has been reported in the literature for helium and flow tube temperature at $25^{\circ} \mathrm{C}[10,13]$. Increasing the water concentration in the flow tube (calculated by Equation 1 and only considering the water amount injected by the sample), the signal intensity of $\mathrm{H}_{3} \mathrm{O}^{+}(\mathrm{m} / z$ 19) precursor ion has progressively decreased, whereas $\mathrm{H}_{3} \mathrm{O}^{+} .\left(\mathrm{H}_{2} \mathrm{O}\right)(\mathrm{m} / \mathrm{z} \quad 37), \mathrm{H}_{3} \mathrm{O}^{+} .\left(\mathrm{H}_{2} \mathrm{O}\right)_{2}(\mathrm{~m} / \mathrm{z} 55)$ and $\mathrm{H}_{3} \mathrm{O}^{+} .\left(\mathrm{H}_{2} \mathrm{O}\right)_{3}(\mathrm{~m} / \mathrm{z} \quad 73)$ ions have been more intense, as shown in Figure 1. In dry air condition, the $\mathrm{H}_{3} \mathrm{O}^{+}(\mathrm{m} / \mathrm{z} 19)$ precursor ion was the most intense precursor ion. However, when $0.50 \%$ vol of $\mathrm{H}_{2} \mathrm{O}$ was present in sample air (equivalent to $7 \times 10^{12}$ molecule $\mathrm{cm}^{-3}$ in flow tube), $\mathrm{H}_{3} \mathrm{O}^{+}(\mathrm{m} / \mathrm{z} 19)$ intensity was reduced of $60 \%$ at a mixing ratio sample-carrier gas equal to $10 \%$. In conditions when more than $0.50 \%$ vol of $\mathrm{H}_{2} \mathrm{O}$ was present in the sample air, the most intense precursor ions were $\mathrm{H}_{3} \mathrm{O}^{+} .\left(\mathrm{H}_{2} \mathrm{O}\right)\left(\mathrm{m} / \mathrm{z}\right.$ 37) and $\mathrm{H}_{3} \mathrm{O}^{+} .\left(\mathrm{H}_{2} \mathrm{O}\right)_{2}(\mathrm{~m} / \mathrm{z} \quad 55)$. The clusters formation by three-body association with nitrogen molecules may also occur in a sequential mechanism, since the signal intensities of $\mathrm{H}_{3} \mathrm{O}^{+} .\left(\mathrm{H}_{2} \mathrm{O}\right)(\mathrm{m} / z$ 37) and $\mathrm{H}_{3} \mathrm{O}^{+} .\left(\mathrm{H}_{2} \mathrm{O}\right)_{2}(\mathrm{~m} / \mathrm{z} 55)$ did not increase significantly, reaching a plateau for water content higher than $2.00 \%$ vol. Meanwhile, $\mathrm{H}_{3} \mathrm{O}^{+} .\left(\mathrm{H}_{2} \mathrm{O}\right)_{3}(\mathrm{~m} / \mathrm{z}$ 73) ion has continued increasing as function of the water concentration.

Even introducing a fixed $\mathrm{H}_{2} \mathrm{~S}$ concentration in sample air (equal to $0.5 \mathrm{ppmv}$ ), the product ions $\mathrm{H}_{3} \mathrm{~S}^{+}(\mathrm{m} / \mathrm{z} \quad 35)$ and $\mathrm{H}_{3} \mathrm{~S}^{+} .\left(\mathrm{H}_{2} \mathrm{O}\right)(\mathrm{m} / \mathrm{z} 53)$ have not resulted in a constant intensity signals, as indicated by Figure 1 . Their values have decreased with $\mathrm{H}_{2} \mathrm{O}$ concentration increase, in agreement with Spanel and Smith [10], which suggested that reverse ionisation reactions also occur in presence of nitrogen (carrier gas). The decrease of $\mathrm{H}_{3} \mathrm{~S}^{+}(\mathrm{m} / z$ 35) with water content seems to be correlated to $\mathrm{H}_{3} \mathrm{O}^{+}(\mathrm{m} / z$ 19) dropping, which could be explained by: (i) the very slow reaction between $\mathrm{H}_{2} \mathrm{~S}$ and water clusters $\mathrm{H}_{3} \mathrm{O}^{+} .\left(\mathrm{H}_{2} \mathrm{O}\right)(\mathrm{m} / z 37), \mathrm{H}_{3} \mathrm{O}^{+} .\left(\mathrm{H}_{2} \mathrm{O}\right)_{2}$ $(\mathrm{m} / \mathrm{z} 55)$ and $\mathrm{H}_{3} \mathrm{O}^{+} .\left(\mathrm{H}_{2} \mathrm{O}\right)_{3}(\mathrm{~m} / \mathrm{z}$ 73) (Bohme et al [22] and Willians et al [11] have reported rate coefficients $<10^{-12} \mathrm{~cm}^{3}$ molecule ${ }^{-1} \mathrm{~s}^{-1}$ ) and (ii) the three-body association reaction of $\mathrm{H}_{3} \mathrm{~S}^{+}$and of $\mathrm{H}_{3} \mathrm{~S}^{+} .\left(\mathrm{H}_{2} \mathrm{O}\right)$ with $\mathrm{H}_{2} \mathrm{O}$ molecules and the consequent fast switching reaction of $\mathrm{H}_{3} \mathrm{~S}^{+} .\left(\mathrm{H}_{2} \mathrm{O}\right)_{n=1,2}$ to $\mathrm{H}_{3} \mathrm{O}^{+} .\left(\mathrm{H}_{2} \mathrm{O}\right)_{n=1,2}$ (since the bond between the $\mathrm{H}_{2} \mathrm{O}$ molecules are stronger than with $\mathrm{H}_{2} \mathrm{~S}$ molecules [10]). Yet from Figure $1, \mathrm{H}_{3} \mathrm{~S}^{+} .\left(\mathrm{H}_{2} \mathrm{O}\right)(\mathrm{m} / \mathrm{z} 53)$ intensity represented less than $1 \%$ of 


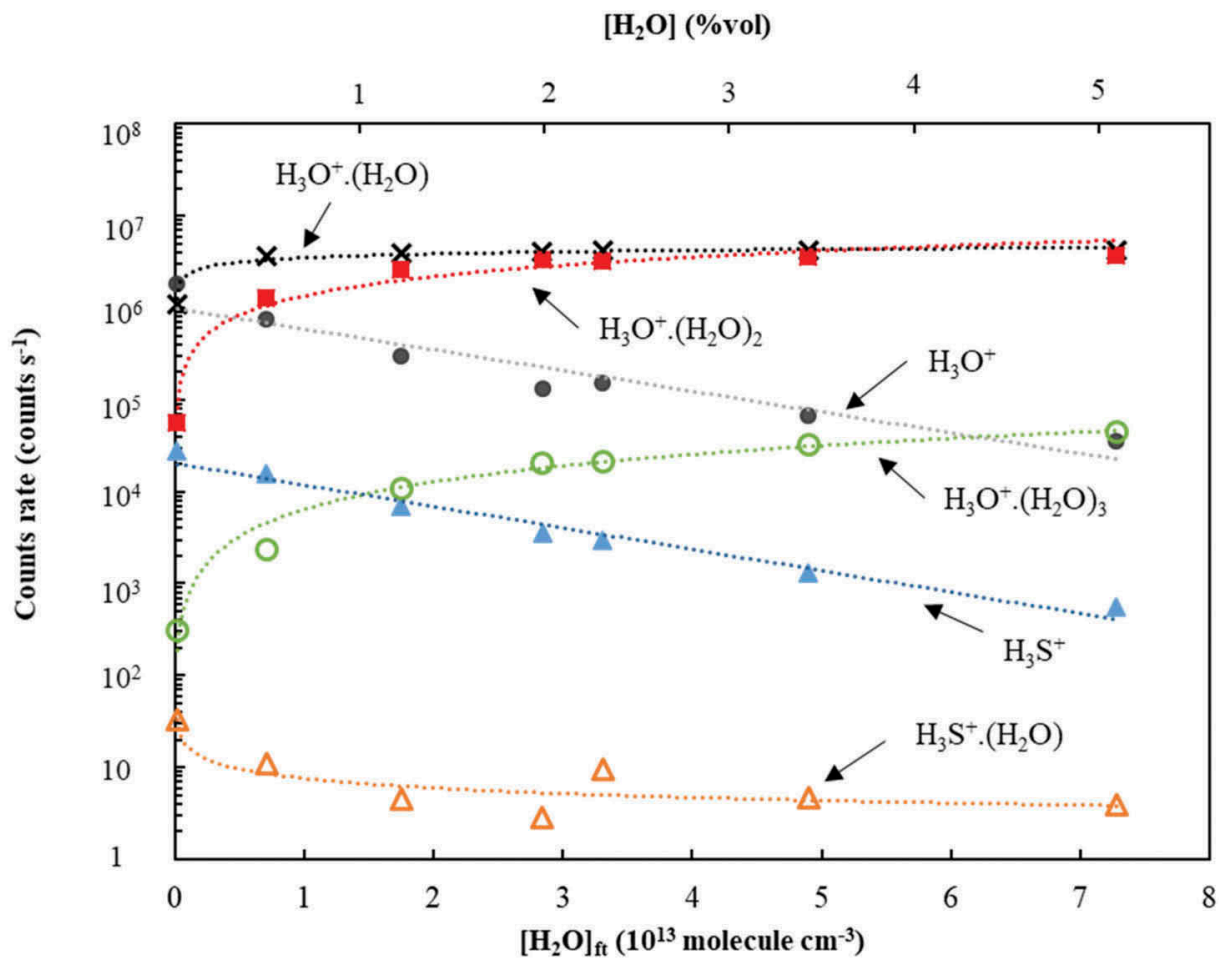

Figure 1. Product and precursor ions counts rate for $\left[\mathrm{H}_{2} \mathrm{~S}\right]$ fixed at 0.5 ppmv as function of $\mathrm{H}_{2} \mathrm{O}$ content in the sample (in \%vol) and its respective $\mathrm{H}_{2} \mathrm{O}$ concentration in flow tube after dilution in nitrogen as carrier gas (in molecule $\mathrm{cm}^{-3}$ and calculated by Equation 1), without considering the $\mathrm{H}_{2} \mathrm{O}$ generated by SIFT/MS ion source. $\mathrm{H}_{3} \mathrm{O}^{+}\left(\mathrm{m} / \mathrm{z} \text { 19) }(\bullet) ; \mathrm{H}_{3} \mathrm{O}^{+} .\left(\mathrm{H}_{2} \mathrm{O}\right)(\mathrm{m} / \mathrm{z} 37)(\mathbf{x}) ; \mathrm{H}_{3} \mathrm{O}^{+} .\left(\mathrm{H}_{2} \mathrm{O}\right)\right)_{2}(\mathrm{~m} / \mathrm{z} 55)(\boldsymbol{\bullet}) ; \mathrm{H}_{3} \mathrm{O}^{+} .\left(\mathrm{H}_{2} \mathrm{O}\right)_{3}(\mathrm{~m} / \mathrm{z} 73)(\mathrm{o})$; $\mathrm{H}_{3} \mathrm{~S}^{+}(\mathrm{m} / \mathrm{z} 35)(\mathbf{\Delta})$ and $\mathrm{H}_{3} \mathrm{~S}^{+}$.( $\left.\mathrm{H}_{2} \mathrm{O}\right)(\mathrm{m} / \mathrm{z} 53)(\Delta)$.

$\mathrm{H}_{3} \mathrm{~S}^{+}(\mathrm{m} / \mathrm{z}$ 35) intensity, which means this product ion can be negligible in Equation (4), without affecting the accurate calculation of $\mathrm{H}_{2} \mathrm{~S}$ concentration.

These variations on precursor and product ions intensities caused by the water amount were reflected on the calculation of $\mathrm{H}_{2} \mathrm{~S}$ concentrations. Applying the rate coefficients proposed by LabSyft ${ }^{\oplus}$ kinetic library (Table 2), $\mathrm{H}_{2} \mathrm{~S}$ concentration measured by SIFT/MS showed a deviation compared to standard calibrations (evidenced by the slopes of the linear regression between calibrated and measured concentrations different from 1), except when the dry air was fed (slope of 1.07), as shown in Figure 2(a). In presence of water, the measured $\mathrm{H}_{2} \mathrm{~S}$ concentrations were falsely high (except for the highest humidity level). The relative gap between the measured and the calibrated $\mathrm{H}_{2} \mathrm{~S}$ concentrations was enlarged with $\mathrm{H}_{2} \mathrm{O}$ concentration until $2.00 \%$ vol (slope values equal to 1.34 and 1.67 for respectively $0.50 \% \mathrm{vol}$ and $2.00 \% \mathrm{vol}$ of $\mathrm{H}_{2} \mathrm{O}$ ). However, from $3.50 \% \mathrm{vol}$ to $5.00 \% \mathrm{vol}$, the opposite effect was identified (slope values equal to 1.18 and 0.88 for respectively $3.50 \% \mathrm{vol}$ and $5.00 \% \mathrm{vol}$ of $\mathrm{H}_{2} \mathrm{O}$ ). Spanel and Smith [10] also reported higher measured $\mathrm{H}_{2} \mathrm{~S}$ concentrations in presence of water $\left(1 \times 10^{13}\right.$ molecule $\mathrm{cm}^{-3}$ in flow tube), which were explained by the large variation of $\mathrm{H}_{3} \mathrm{O}^{+}$precursor ions due to clusters formation. 

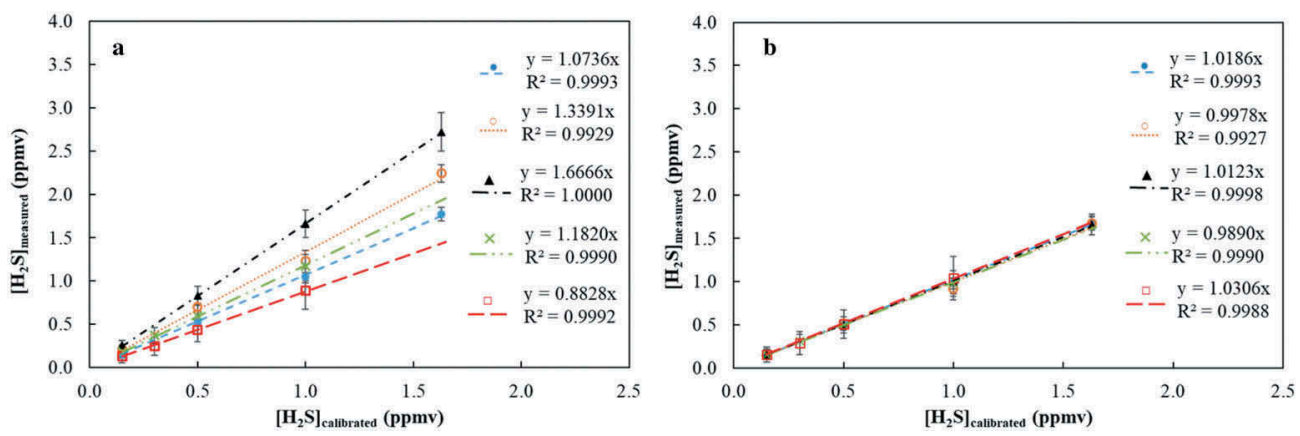

Figure 2. Comparison between measured and calibrated $\mathrm{H}_{2} \mathrm{~S}$ concentrations for 5 humidity levels and its respective linear regression (dotted lines): $0.01 \%$ vol of $\mathrm{H}_{2} \mathrm{O}(\bullet) ; 0.50 \%$ vol of $\mathrm{H}_{2} \mathrm{O}(0) ; 2.00 \%$ vol of $\mathrm{H}_{2} \mathrm{O}(\boldsymbol{\Delta}) ; 3.50 \%$ vol of $\mathrm{H}_{2} \mathrm{O}(\boldsymbol{x})$ and $5.00 \%$ vol of $\mathrm{H}_{2} \mathrm{O}$ (口). (a) Considering the ionisation rate coefficients values shown in Table 2. (b) Considering the apparent product formation rate after correcting according to water amount.

Therefore, it is possible to conclude that the rate coefficients values used by LabSyft ${ }^{\oplus}$ kinetic library did not satisfactorily describe the ionisation reaction of $\mathrm{H}_{2} \mathrm{~S}$ by $\mathrm{H}_{3} \mathrm{O}^{+}$precursor ion in presence of water when applying flow tube temperature at $119^{\circ} \mathrm{C}$ and nitrogen as carrier gas. Applying a similar methodology proposed to measurements of $\mathrm{H}_{2} \mathrm{~S}$ using PTR/MS $[9,12]$, the rate coefficient of $\mathrm{H}_{3} \mathrm{O}^{+}(\mathrm{m} / z$ 19) was corrected integrating the water concentration and neglecting all reactions of $\mathrm{H}_{2} \mathrm{~S}$ with water clusters $\mathrm{H}_{3} \mathrm{O}^{+} .\left(\mathrm{H}_{2} \mathrm{O}\right)\left(\mathrm{m} / \mathrm{z}\right.$ 37), $\mathrm{H}_{3} \mathrm{O}^{+} .\left(\mathrm{H}_{2} \mathrm{O}\right)_{2}(\mathrm{~m} / \mathrm{z} 55)$ and $\mathrm{H}_{3} \mathrm{O}^{+} .\left(\mathrm{H}_{2} \mathrm{O}\right)_{3}(\mathrm{~m} / \mathrm{z}$ 73). Therefore, these water clusters ions were no more considered as precursor ions in LabSyft ${ }^{\oplus}$ software. The apparent product formation rate $\left(k^{2} p_{19}\right)$ for the $\mathrm{H}_{3} \mathrm{O}^{+}(\mathrm{m} / z$ 19) precursor ion was calculated multiplying the rate coefficient of $\mathrm{H}_{3} \mathrm{O}^{+}(\mathrm{m} / \mathrm{z}$ 19) at dry air $\left(1.6 \times 10^{-9} \mathrm{~cm}^{3}\right.$ molecule $\left.\mathrm{s}^{-1}\right)$ by the ratio of the $\mathrm{H}_{2} \mathrm{~S}$ concentration measured by SIFT/MS (with only $\mathrm{H}_{3} \mathrm{O}^{+}$as precursor ion and rate coefficient of dry air) and the calibrated $\mathrm{H}_{2} \mathrm{~S}$ concentration. The calculation of $\mathrm{kap}_{19}$ was carried out for all levels of $\mathrm{H}_{2} \mathrm{~S}$ and $\mathrm{H}_{2} \mathrm{O}$ concentrations and their values are presented in Figure 3 with their respective uncertainties. These ones were calculated by propagation error method, which includes the standard deviation of kap $_{19}$ calculated for each $\mathrm{H}_{2} \mathrm{~S}$ concentration level and the uncertainty from the experimental dispositive to generate the diluted gas mixture (estimated as $10 \%$ to lowest $\mathrm{H}_{2} \mathrm{~S}$ concentrations). In agreement with $\mathrm{Li}$ et al results [9], the apparent rate coefficient has shown an exponential relationship with humidity level. The value of $\operatorname{kap}_{19}$ largely depends on the humidity level, dropping by about a factor of 100 in condition with high water amount (5.00\%vol). The increase of the $\mathrm{H}_{2} \mathrm{O}$ concentration probably enhances the reverse ionisation reaction (from $\mathrm{H}_{3} \mathrm{~S}^{+}$ to $\mathrm{H}_{2} \mathrm{O}$ ), reducing, therefore, the apparent rate coefficient of the reaction between $\mathrm{H}_{2} \mathrm{~S}$ with $\mathrm{H}_{3} \mathrm{O}^{+}$.

The $\mathrm{H}_{2} \mathrm{~S}$ concentrations determined from the corrected values of rate coefficients of precursor ion $\mathrm{H}_{3} \mathrm{O}^{+}\left(\mathrm{m} / \mathrm{z}\right.$ 19) for each level of $\mathrm{H}_{2} \mathrm{O}$ concentration are shown in Figure 2(b), which are in excellent accord with the calibrated $\mathrm{H}_{2} \mathrm{~S}$ concentrations (all slopes are close to 1 with excellent correlation coefficients). However, the major drawback of this correction method by $\mathrm{kap}_{19}$ is that accurate quantification of $\mathrm{H}_{2} \mathrm{~S}$ by SIFT/MS is only possible if the humidity level of sample is known. Meanwhile, at a fixed level of humidity, the 


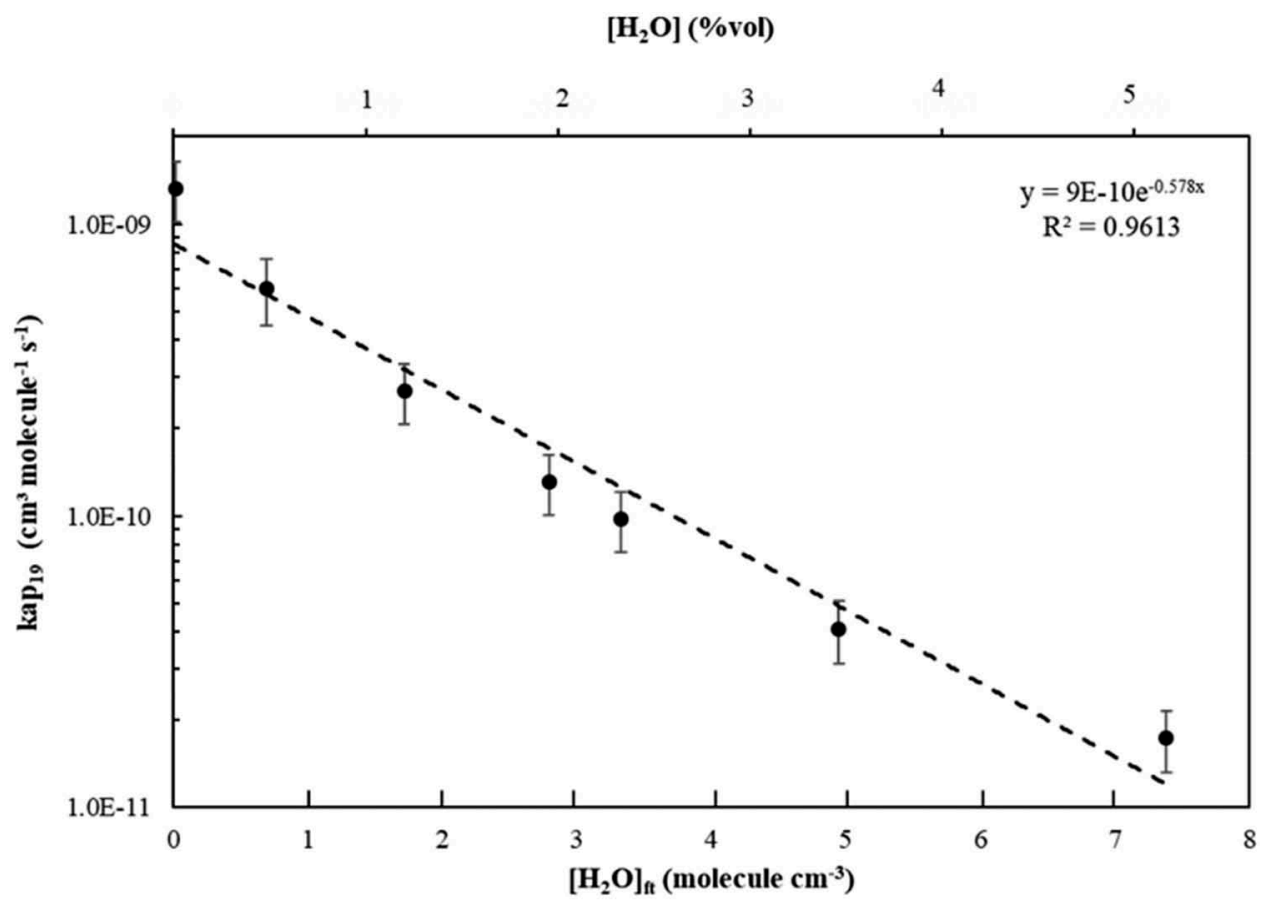

Figure 3. Apparent product formation rate of precursor ion $\mathrm{H}_{3} \mathrm{O}^{+}\left(m / z\right.$ 19) $\left(\mathrm{kap}_{19}\right)$ as function of $\mathrm{H}_{2} \mathrm{O}$ concentration.

$\mathrm{H}_{2} \mathrm{~S}$ concentration followed a linear correlation ( $\mathrm{R}^{2}$ close to 1 ), which means that even if the absolute value of $\mathrm{H}_{2} \mathrm{~S}$ is not accurate, $\mathrm{H}_{2} \mathrm{~S}$ concentrations is always proportional to the signal intensity of $\mathrm{H}_{3} \mathrm{~S}^{+}(\mathrm{m} / \mathrm{z} 35)$ product ion (for the concentration range studied in this work).

\subsection{Analytical performance}

The $\mathrm{H}_{2} \mathrm{O}$ concentration has also shown a serious impact on SIFT/MS sensitivity for $\mathrm{H}_{2} \mathrm{~S}$, as

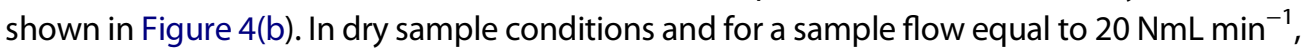
each ppmv of $\mathrm{H}_{2} \mathrm{~S}$ generated around 60000 counts s${ }^{-1}$ at $\mathrm{H}_{3} \mathrm{~S}^{+}(\mathrm{m} / \mathrm{z} 35)$. However, when $1.00 \%$ vol of $\mathrm{H}_{2} \mathrm{O}$ were present in sample gas, $\mathrm{H}_{3} \mathrm{~S}^{+}(\mathrm{m} / z 35)$ intensity dropped to 15000 counts s ${ }^{-1}$ for each ppmv of $\mathrm{H}_{2} \mathrm{~S}$ injected in the sample. This reduction of the sensitivity of SIFT/MS could also be observed in Figure 1: at a fixed $\mathrm{H}_{2} \mathrm{~S}$ concentration, $\mathrm{H}_{3} \mathrm{~S}^{+}(\mathrm{m} / \mathrm{z} 35)$ product ion gradually decreased with the humidity level augmentation.

The sensitivity-reducing phenomena with humidity caused two main consequences on analytical performance of SIFT/MS: (i) the increasing of LOD and LOQ and (ii) the raise of uncertainty for $\mathrm{H}_{2} \mathrm{~S}$ measurements. LOD and LOQ were calculated for five different levels of humidity and considering a measurement time of $100 \mathrm{~s}$ (Table 3). Comparing, for example, LOQ at dry condition to $4.00 \% \mathrm{vol}$ of $\mathrm{H}_{2} \mathrm{O}$, the strong effect of water interference is clearly observed: LOQ has increased from $0.040 \pm 0.008$ ppbv to $1.4 \pm 0.3 \mathrm{ppbv}$. Although, even in critical humidity conditions, LOD of SIFT/MS for 

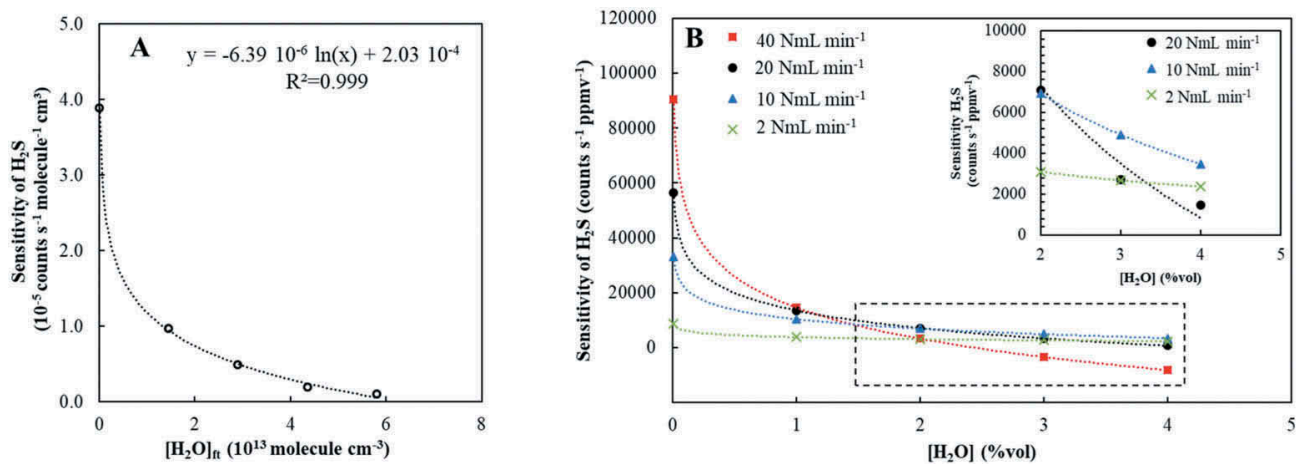

Figure 4. The sensitivity of SIFT/MS for $\mathrm{H}_{2} \mathrm{~S}$ quantification as function of humidity level. (a) Experimental values obtained with $\varphi_{s}=20 \mathrm{NmL} \mathrm{min}{ }^{-1}$ and considering the sensitivity of $\mathrm{H}_{2} \mathrm{~S}$ and the $\mathrm{H}_{2} \mathrm{O}$ content in the flow tube. (b) Effect of sample flow on the sensitivity for 4 sample flows: $\varphi_{s}=40 \mathrm{NmL} \mathrm{min}^{-1}(\mathbf{m}), \varphi_{s}=20 \mathrm{NmL}$ $\min ^{-1}(\bullet), \varphi_{\mathrm{s}}=10 \mathrm{NmL} \min ^{-1}(\boldsymbol{\Delta})$ and $\varphi_{\mathrm{s}}=2 \mathrm{NmL} \min ^{-1}(\boldsymbol{X})$.

Table 3. LOD and LOQ of SIFT/MS for $\mathrm{H}_{2} \mathrm{~S}$ (considering a measurement time of $100 \mathrm{~s})$.

\begin{tabular}{lcc}
\hline$\left[\mathrm{H}_{2} \mathrm{O}\right](\% \mathrm{vol})$ & LOD $(\mathrm{ppbv})$ & LOQ $(\mathrm{ppbv})$ \\
\hline 0.01 & 0.02 & 0.04 \\
1.20 & 0.05 & 0.1 \\
2.00 & 0.1 & 0.2 \\
3.00 & 0.4 & 0.7 \\
4.00 & 0.8 & 1.4 \\
\hline
\end{tabular}

$\mathrm{H}_{2} \mathrm{~S}$ measurements has resulted in lower values compared to GC-based methods usually coupled with TD devices: 0.77 ppbv vs 3.8 ppbv [7].

We also observed that, in SIFT/MS, uncertainty of signal intensity is tightly connected to its absolute value, and therefore, the less intense the signal, the bigger the uncertainty. This observation can be exemplified in Figure 5, where four different levels of $\mathrm{H}_{2} \mathrm{~S}$ concentrations ( 0.05 ppmv; 0.15 ppmv; 0.5 ppmv and 1 ppmv) are disposed with their respective uncertainties (the standard deviation of a $400 \mathrm{~s}$ measurement time analysis measured by SIFT/MS) as function of $\mathrm{H}_{2} \mathrm{O}$ concentration. It is clear that the highest uncertainty (around 35\%) was obtained at the lowest value of $\mathrm{H}_{2} \mathrm{~S}$ concentration (0.05 ppmv) coupled with the highest humidity level $\left(4.00 \%\right.$ vol of $\left.\mathrm{H}_{2} \mathrm{O}\right)$, whereas at 1.0 ppmv of $\mathrm{H}_{2} \mathrm{~S}$ and $4.00 \%$ vol of $\mathrm{H}_{2} \mathrm{O}$, the relative uncertainty was reduced to $10 \%$. In summary, low concentration of $\mathrm{H}_{2} \mathrm{~S}$ in combination with high humidity is a critical point for measuring $\mathrm{H}_{2} \mathrm{~S}$ by SIFT/MS. The augmentation of the relative uncertainty related to the water content becomes less noticeable as the $\mathrm{H}_{2} \mathrm{~S}$ concentration increases, since the intensity of $\mathrm{H}_{3} \mathrm{~S}^{+}(\mathrm{m} / \mathrm{z} 35)$ also rises.

The practical uncertainties obtained were greater than the LOQ values, probably because of the uncertainty of the experimental set up to generate the diluted gas mixture. This uncertainty was estimated to $10 \%$ for the lowest $\mathrm{H}_{2} \mathrm{~S}$ concentrations and to $2 \%$ for the highest $\mathrm{H}_{2} \mathrm{~S}$ concentrations.

The negative effect of humidity on the sensitivity of $\mathrm{H}_{2} \mathrm{~S}$ could be minimise by decreasing the sample flow of the SIFT/MS device, since the lower the quantity of 

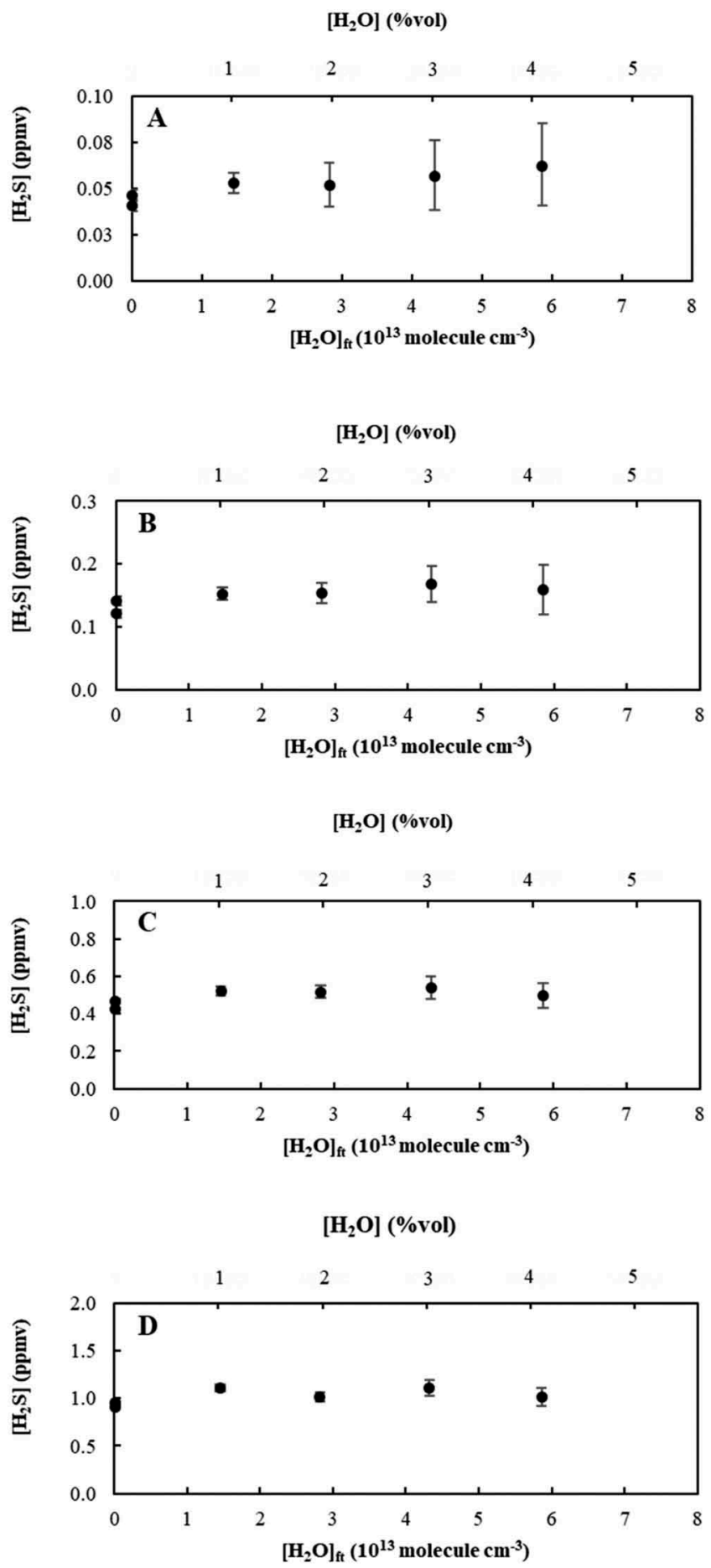

Figure 5. Uncertainty related to $\mathrm{H}_{2} \mathrm{O}$ and $\mathrm{H}_{2} \mathrm{~S}$ levels of concentration. The $\mathrm{H}_{2} \mathrm{~S}$ concentration axis is limited to the double of the calibrated concentration to express the relative error (calculated as the standard deviation of a $400 \mathrm{~s}$ measurement time analysis by SIFT/MS). (a) $0.05 \mathrm{ppmv}$ of $\mathrm{H}_{2} \mathrm{~S}$. (b) 0.15 ppmv of $\mathrm{H}_{2} \mathrm{~S}$. (c) 0.5 ppmv of $\mathrm{H}_{2} \mathrm{~S}$ and (d) 1.0 ppmv of $\mathrm{H}_{2} \mathrm{~S}$. 
water present in the flow tube, the lower the clusters formation. Meanwhile, for a same concentration level in the sample flow, a decrease of the sample flow also reduces the signal intensity of $\mathrm{H}_{3} \mathrm{~S}^{+}(\mathrm{m} / \mathrm{z} 35)$, which could affect the analysis uncertainty.

In order to consider these two clearly compensating effects and, hence, to obtain an optimum sample flow in extreme air humidity condition, a theoretical study was carried out. We have considered that the sensitivity of $\mathrm{H}_{2} \mathrm{~S}$ (in counts $\mathrm{s}^{-1}$ molecule ${ }^{-1} \mathrm{~cm}^{3}$ ) associated to the $\mathrm{H}_{2} \mathrm{~S}$ concentration in the flow tube - would present the same profile as function of the $\mathrm{H}_{2} \mathrm{O}$ concentration in flow tube (in molecule $\mathrm{cm}^{-3}$ ) regardless of the sample flow. From the experimental values obtained with $20 \mathrm{NmL} \min ^{-1}$ (the only sample flow experimentally feasible), a natural logarithm expression ( $R^{2}$ equal to 0.999) was adjusted, correlating the sensitivity of $\mathrm{H}_{2} \mathrm{~S}$ (in counts $\mathrm{s}^{-1}$ molecule $\mathrm{cm}^{-1}$ ) with the $\left[\mathrm{H}_{2} \mathrm{O}\right]_{\mathrm{ft}}$ (in molecule $\mathrm{cm}^{-3}$ ) as shown in Figure 4(a). Thanks to this expression, we could predict the variation of the sensitivity of $\mathrm{H}_{2} \mathrm{~S}$ (in counts $\mathrm{s}^{-1} \mathrm{ppmv}^{-1}$ ) as a function of $\mathrm{H}_{2} \mathrm{O}$ content (in \%vol) for three different sample flows $\left(40 \mathrm{NmL} \mathrm{min}{ }^{-1}, 15 \mathrm{NmL} \mathrm{min}^{-1}\right.$ and $2 \mathrm{NmL} \mathrm{min}^{-1}$ ). These prediction curves are presented in Figure 4(b) simultaneously with the experimental one $\left(20 \mathrm{NmL} \mathrm{min}^{-1}\right)$.

The Figure 4(b) shows that the increase of the sample flow $\left(40 \mathrm{NmL} \mathrm{min}{ }^{-1}\right)$ is disadvantageous for $\mathrm{H}_{2} \mathrm{~S}$ quantification in extreme humidity conditions (superior to $2.00 \%$ vol of $\mathrm{H}_{2} \mathrm{O}$ ), given that the sensitivity of $\mathrm{H}_{2} \mathrm{~S}$ decreases vertiginously depending on $\mathrm{H}_{2} \mathrm{O}$ concentration. As expected, the decrease of the sample flow (from $20 \mathrm{NmL}$ $\min ^{-1}$ to $10 \mathrm{NmL} \mathrm{min}^{-1}$ ) was beneficial since a higher value of sensitivity was obtained for $\mathrm{H}_{2} \mathrm{O}$ content superior to $2.00 \%$ vol. Nevertheless, when the sample

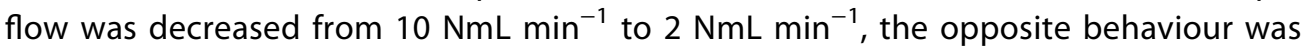
identified: at $4.00 \%$ vol of $\mathrm{H}_{2} \mathrm{O}$, the sensitivity at $2 \mathrm{NmL} \mathrm{min}^{-1}$ was lower than at

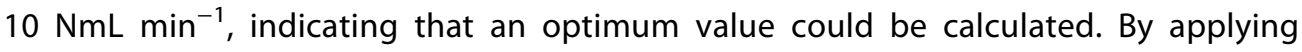
the Generalized Reduced Gradient (GRG) nonlinear method, the optimum sample

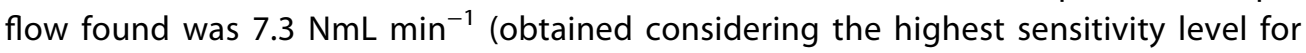
$\left[\mathrm{H}_{2} \mathrm{O}\right]$ at $4 \%$ vol).

\section{Conclusion}

The $\mathrm{H}_{2} \mathrm{~S}$ quantification in real-time analysis can be satisfactorily carried out by SIFT/MS using nitrogen as carrier gas, even in extreme air humidity conditions (from 0.01 to $5.00 \% \mathrm{vol}$ of $\mathrm{H}_{2} \mathrm{O}$ ), without requiring any dryer or water trap devices. For that, in order to compensate the water interference, the rate coefficient of the $\mathrm{H}_{2} \mathrm{~S}_{-} \mathrm{H}_{3} \mathrm{O}^{+}$ionisation reaction in SIFT/MS analysis must be corrected regarding the water content and thus, the humidity in the gas matrix must be known.

This study has also evidenced that the use of nitrogen as carrier gas requires precaution regarding the parameters previously obtained using helium. For compounds which clusters formation and/or reverse proton transfer may occur - such as $\mathrm{H}_{2} \mathrm{~S}$ - complementary studies are necessary for accurate quantification by SIFT/MS.

In addition, we found that (i) the humidity decreased the sensitivity of SIFT/MS for $\mathrm{H}_{2} \mathrm{~S}$ quantification and (ii) the measurement uncertainty is higher with low signal intensity. Therefore, the association of low $\mathrm{H}_{2} \mathrm{~S}$ concentration and high humidity is a critical point for $\mathrm{H}_{2} \mathrm{~S}$ measurements. Uncertainty values around $35 \%$ were reported in this critical condition (for the standard sample flow applied in study). A decrease of 
the sample flow of SIFT/MS device is suggested if the $\mathrm{H}_{2} \mathrm{~S}$ quantification has to be carried out in extreme humidity conditions. LOD and LOQ also increased due to the humidity raise, but they were still lower than the values obtained with the traditional analytical method (TD-GC).

\section{Acknowledgments}

The authors gratefully acknowledge the financial support for the research by French National Agency for Research and Technology and Agro Innovation International (CIFRE 2015/1233).

\section{Disclosure statement}

No potential conflict of interest was reported by the authors.

\section{Funding}

This work was supported by the French National Agency for Research and Technology and Agro Innovation International (CIFRE 2015/1233).

\section{ORCID}

Romain Richard (D) http://orcid.org/0000-0002-6037-8254

Marie-Hélène Manero (D) http://orcid.org/0000-0002-8598-4250

Frédéric Violleau (D) http://orcid.org/0000-0002-2571-5083

Valérie Simon (D) http://orcid.org/0000-0002-2624-157X

\section{References}

[1] A.R. Ravishankara, Y. Rudich, R. Talukdar and S.B. Barone, Philos. Trans. R. Soc. B Biol. Sci. 352, 171 (1997). doi:10.1098/rstb.1997.0012.

[2] S.K. Pandey and K. Kim, Environ. Sci. Technol. 43, 3020 (2009). doi:10.1021/es901110m.

[3] K.H. Kim, Environ. Sci. Technol. 39, 6765 (2005). doi:10.1021/es050497i.

[4] E. Borrás, L.A. Tortajada-Genaro and A. Muñoz, Talanta 148, 472 (2016). doi:10.1016/j. talanta.2015.11.021.

[5] K.C. Li and D. Shooter, Int. J. Environ. Anal. Chem. 84, 749 (2004). doi:10.1080/ 03067310410001729619.

[6] E.C. Sivret, B. Wang, G. Parcsi and R.M. Stuetz, Water Res. 88, 308 (2016). doi:10.1016/j. watres.2015.10.020.

[7] B. Wang, E.C. Sivret, G. Parcsi and R.M. Stuetz, Talanta 137, 71 (2015). doi:10.1016/j. talanta.2014.11.072.

[8] A.S. Brown, A.M.H. van der Veen, K. Arrhenius, A. Murugan, L.P. Culleton, P.R. Ziel and J. Li, TrAC - Trends Anal. Chem. 64, 42 (2015). doi:10.1016/j.trac.2014.08.012.

[9] R. Li, C. Warneke, M. Graus, R. Field, F. Geiger, P.R. Veres, J. Soltis, S.M. Li, S.M. Murphy, C. Sweeney, G. Pétron, J.M. Roberts and J. De Gouw, Atmos. Meas. Tech. 7, 3597 (2014). doi:10.5194/amt-7-3597-2014.

[10] P. Spanel and D. Smith, Rapid Commun. Mass Spectrom. 14, 1136 (2000).

[11] T.L. Williams, N.G. Adams and L.M. Babcock, Int. J. Mass Spectrom. 172, 149 (1998). doi:10.1016/s0168-1176(97)00081-5.

[12] A. Feilberg, D. Liu, A.P.S. Adamsen, M.J. Hansen and K.E.N. Jonassen, Environ. Sci. Technol. 44, 5894 (2010). doi:10.1021/es100483s. 
[13] P. Spanel and D. Smith, Rapid Commun. Mass Spectrom. 14, 1898 (2000).

[14] B. Anet, M. Lemasle, C. Couriol, T. Lendormi, A. Amrane, P. Le Cloirec, G. Cogny and R. Fillières, J. Environ. Manage. 128, 981 (2013). doi:10.1016/j.jenvman.2013.06.028.

[15] C. Domeno, A. Rodríguez-Lafuente, J.M. Martos, R. Bilbao and C. Nerín, Environ. Sci. Technol. 44, 2585 (2010). doi:10.1021/es902735g.

[16] J.R. Kastner and K.C. Das, J. Air Waste Manag. Assoc. 52, 459 (2002). doi:10.1080/ 10473289.2002.10470800.

[17] D. Smith and P. Spanel, Mass Spectrom. Rev. 24, 661 (2005). doi:10.1002/mas.20033.

[18] G.J. Francis, D.B. Milligan and M.J. McEwan, Anal. Chem. 81, 8892 (2009). doi:10.1021/ ac901486c.

[19] D. Materić, D. Bruhn, C. Turner, G. Morgan, N. Mason and V. Gauci, Appl. Plant Sci. 3, 1500044 (2015). doi:10.3732/apps.1500044.

[20] C. Guimbaud, V. Catoire, A. Bergeat, E. Michel, N. Schoon, C. Amelynck, D. Labonnette and G. Poulet, Int. J. Mass Spectrom. 263, 276 (2007). doi:10.1016/j.ijms.2007.03.006.

[21] P. Spanel and D. Smith, Am. Soc. Mass Spectrom. 12, 863 (2001).

[22] D.K. Bohme, G.I. Mackay and S.D. Tanner, J. Am. Chem. Soc. 101, 3724 (1979). doi:10.1021/ ja00508a003.ke.

[23] D.B. Milligan, G.J. Francis, B.J. Prince and M.J. McEwan, Anal. Chem. 79, 2537 (2007). doi:10.1021/ac0622678.

[24] B.M. Ross, BMC Res. Notes. 1 (41), 1 (2008). doi:10.1186/1756-0500-1-41.

[25] P. Spanel and D. Smith, Med. Biol. Eng. Comput. 34, 409 (1996). doi:10.1007/BF02523843. 